\title{
Okostelefon a családban - Mennyire járulunk hozzá szülőként gyermekeink médián keresztüli manipulációjához
}

\author{
DOI : 10.46522/S.2021.02.05
}

\author{
VARGANCSIK-THÖRIK Krisztina Iringó PhD \\ University of Arts Târgu Mureș \\ vargancsik.iringo@gmail.com
}

\begin{abstract}
Smartphone in the Family - How Much We as Parents Contribute to the Manipulation of Our Children Through Media

Nowadays, smartphones interweave family life. Affordable prices, easy access, expanding network coverage, and more and more practical applications make them a must-have in everyday life. Not only do adults use the smartphone, but also their children do so, often every family member has a device. From a very young age, it starts to be used for entertaining children, and then, from the first years of school, to keep them connected to parents. This way, they become independent users at a very early age, and this also entails risks and the possibility of media manipulation that parents are not always aware of. We asked more than 300 Transylvanian parents about the place of smartphones in their families and examined their awareness of regulating their children on the use of these devices.
\end{abstract}

Key words: parents; media education; smartphone.

\section{Bevezető}

Jelenleg az okostelefonok teljes mértékben behálózzák a családok életét. Elérhető áruk, a könnyü hozzáférés, az egyre kiterjedtebb hálózati lefedettség, az egyre több praktikus alkalmazás nélkülözhetetlenné teszi őket a mindennapokban. De nem csak a felnőttek használják az okostelefont, hanem gyermekeik is. Gyakran a család minden tagja rendelkezik egy-egy készülékkel. Nagyon kis kortól elkezdődik a gyermekek szórakoztatására való felhasználás, majd az első iskolai évektől az ezen keresztüli kapcsolattartás, az önálló használat. Ez az önálló használat kockázatokkal, a médián keresztüli manipuláció lehetőségeivel is jár, amelyeknek a szülők nincsenek minden esetben tudatában. Több mint 300 romániai magyar szülöt kérdeztünk az okostelefonok helyéröl a családban, és megvizsgáltuk, hogy mennyire tudatos az okostelefonok gyermekeik általi használatának szabályozása.

Romániában 2019-re közel háromszorosára, azaz 68\%-ra nőtt azon 16 és 74 év közötti lakosok száma, akik mobileszközöket használnak az internethez való kapcsolódáshoz, 2014-hez képest, amikor ez az arány mindössze 25\% volt (Eurostat 2020). Figyelembe 
véve, hogy ez a hirtelen növekedés nem jár együtt az álhírek kiszürésére és a médián keresztül történő manipuláció tudatosítására vonatkozó felnőttoktatással, feltételezhető, hogy nagyon sok személy esik ezek áldozatául. Illetve az is feltételezhető, hogy a mobileszközök segítségével történő internetezés aránya ugrásszerü növekedést fog mutatni a 2019-2021-es időszakban, amikor Romániában az oktatáshoz való hozzáférés céljából többszázezer internetes bérlettel rendelkező okostelefont, tabletet, laptopot osztottak szét országszerte a koronavírus okozta pandémia miatt online térbe kényszerült közoktatáshoz való hozzáférés megkönnyítésére (144/2020.08.24-es Sürgősségi Kormányrendelet).

Ezek az eszközök elsősorban szociálisan hátrányos helyzetủ családokba érkeztek, ahol gyakran nem csak a gyermekek, hanem a szülők sem rendelkeztek internethozzáféréssel ellátott okoseszközzel. Így nem csak az online média használatával kapcsolatos ismeretek korlátozottak a fent említett családokban, hanem az online média általi manipuláció kockázata is jelentős.

\section{Médiahasználat és szülői mediáció}

Bár kutatók a médiahasználattal kapcsolatos szülői mediáció különböző válfajait azonosították, jelen tanulmányban az általánosan elfogadott, Valkenburg, Krcmar, Peeters és Marseille által 1999-ben bevezetett három stratégiát használom kiindulópontnak. Ezek a korlátozó, aktív és együttes felhasználás. A korlátozó mediáció a szabályok, korlátozások bevezetésére utal, különös tekintettel az időtartamra és a tartalom típusára. Az aktív mediáció az oktató stratégiákban való együttes részvételre utal, kiemelve a médiahasználatra vonatkozó magyarázatok és beszélgetések fontosságát. Végül az együttes felhasználás a közös nézés vagy játék cselekedetére utal, azaz a szülők megosztják a médiaidőt a gyermekekkel, gyakran anélkül, hogy megbeszélnék a felhasznált idő mennyiségét vagy a tartalom típusát. A szülői mediálás három típusa közül a korlátozó és az aktív különösen releváns az okostelefonok használata szempontjából, míg az együttes használat kevésbé jellemző, hiszen a gyermekek és fiatalok elsősorban a kortársakkal használják közösen, illetve lesik el, kísérletezik ki a mobileszközök használatára vonatkozó eljárásokat, próbálják ki az új alkalmazásokat és játékokat, és gyakran előfordul, hogy ők tanítják a szüleiket az okostelefonok használatára.

A szülöi mediáció típusa nagymértékben összefügg a családon belül használt kommunikációs stílussal, és ez befolyásolja a családon belül történő médiafogyasztással kapcsolatos nevelést. A családi kommunikációs stílusok következetes, finom útmutatást adnak a gyermek viselkedéséhez és információszerzéséhez (Fujioka és Austin 2002). A tanulmány szerint a szociálorientált szülők hajlamosak szabályokat alkotni vagy besorolási rendszereket használni, de kevésbé használják a kritikus vitát. Ez azért problematikus, mert a reflexióra ösztönző nyílt vita fontosnak tünik az értékes médiamüveltségi készségek fejlesztése szempontjából. 
A kutatás azt sugallja, hogy ha a szülői mediáció célja az, hogy megtanítsa a gyermekeket kritikus készségekre, hogy segítsen a gyermeknek megbirkózni a médiaüzenetekkel, akkor ez úgy érhető el a leghatékonyabban, ha (a) a szülők olyan mediációban vesznek részt, amely reflexióra ösztönöz; (b) a gyermek a szülők szándéka szerint értelmezi az üzeneteket, ami szintén nyílt megbeszélést igényel; és (c) a gyermek készségesen elfogadja a szülök üzeneteit vagy a szülök által jóváhagyott példákat. A tanulmányból származó adatok arra utalnak, hogy a koncepció-orientált szülői nevelés olyan mediációs stratégiákhoz vezet, amelyek elérik ezeket a célokat. Az eredmények továbbá azt sugallják, hogy a szociálorientált szülői nevelés bizonyos esetekben kontraproduktív eredményekhez vezethet, ezért az ilyen környezetben nevelkedö gyermekeknek nagyobb szükségük lehet a médiamüveltséget támogató külső beavatkozásokra (Fujioka és Austin 2002).

Livingstone és Helpster (2008) szerint a szülők előnyben részesítik a szociális mediációt a technikaival szemben, azaz az aktív együtthasználatot részesítik előnyben a technikai korlátozásokkal és megfigyelési gyakorlatokkal szemben. Nem sikerült azonban bizonyítaniuk azt a feltételezést, hogy a mediáció fokozása csökkentené a kockázatokat.

Ugyanakkor 25 európai országra kiterjedő kutatásuk eredményeként Livingstone és tsai. (2011) öt olyan stratégiát határoztak meg, amely szülői mediálási módszerként segíthet az iskoláskorú gyermekek digitális müveltségének fejlődésében. Ezek a következők:

- az internethasználatról való aktív társalgás a gyermekkel - az internetes tartalmakról és az online tevékenységekről való beszélgetés, a közelben ülés, miközben a gyermek online van, és a gyermek online tapasztalatainak aktív megosztásának teret adni

- az internet biztonságának aktív közvetitése - olyan tevékenységek ajánlása a gyermeknek, amelyek az internet biztonságosabb és felelősségteljesebb használatának előmozdítására buzdítják őt

- szabályozás - olyan szabályok meghatározása, amelyek korlátozzák az online eltöltött időt, a használat helyét, valamint a tartalmat és a tevékenységeket

- müszaki korlátozások - szoftverek és technikai eszközök használata a gyermekek online tevékenységeinek szürésére, korlátozására és figyelemmel kísérésére

- monitorozás - a gyermekek online gyakorlatának ellenőrzése használat után

Következésképpen a szülői mediáció változatos formái különböző formában befolyásolják a gyermekek médiahasználatát, de nem tudják kizárni a kockázatokat és a médián keresztuili manipuláció lehetőségét.

\section{A kutatás célja és hipotézisei}

Kutatásunk célja az volt, hogy erdélyi viszonylatban megvizsgáljuk a szülők ismereteit a gyermekeik online barátkozási szokásaira vonatkozóan, illetve a szülői mediáció formáit a gyermekek okostelefon-használata tekintetében. Ebből a célból online kérdőívet 
juttattunk el a szülőkhöz Erdély-szerte 2020 februárjában, amelyre 336 értelmezhető válasz érkezett be. Az adatokat SPSS, Excel és MAXQDA segítségével dolgoztuk fel.

Feltételezésünk az volt, hogy az erdélyi magyar szülök:

1. nem tudnak eleget gyermekeik online barátkozási szokásairól,

2. a szülői mediáció korlátozó formáit részesítik előnyben az aktív mediációval szemben, illetve

3. nincsenek tudatában az okoseszközök használatában rejlő kockázatokkal.

\section{A kutatás mintája}

A kutatás mintája 336 kiskorú gyermek(ek)et nevelő szülőből állt, ezek nagy része nő (276, azaz 82\%) és mindössze 18\%-a férfi (60). Életkor szerinti eloszlásukat tekintve 131, azaz a válaszadók 39\%-a 40-44 év közötti, 89, azaz 26\% 35-39 év közötti, 49, azaz 15\% 30-34 év közötti, 36, azaz 11\% 45-49 év közötti, 21, azaz 6\% 50 év feletti, 9, azaz 3\% 25-29 év közötti és 1 válaszadó 18-24 év közötti. Az életkor és a nemek közötti összefüggés az alábbi diagramon látható: mind a nők, mind a férfiak esetében a legmagasabb a 40-44, illetve a 35-39 éves korosztály aránya (1. ábra).

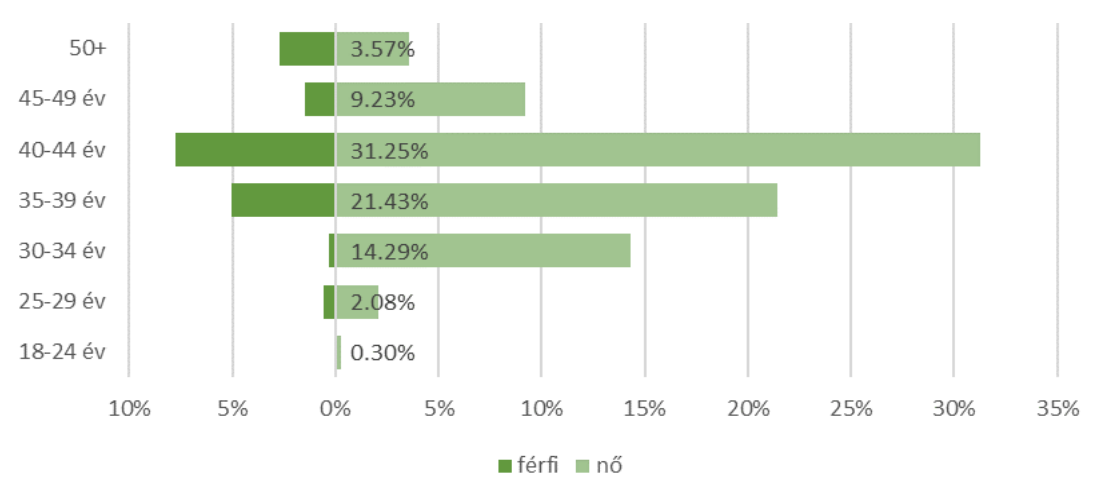

1. ábra - A minta életkor és nemek szerinti eloszlása

A válaszadók végzettség szerinti eloszlása alapján (2. ábra) kijelenthető, hogy a minta nagyrészt értelmiségiekből áll, magas az egyetemi alapképzésben (39\%), egyetemi mesterképzésben (26\%), föiskolai képzésben (13\%), illetve doktori képzésben (4\%) részesült válaszadók száma, azaz összesen $82 \%$. 
Vargancsik-Thörik Krisztina Iringó

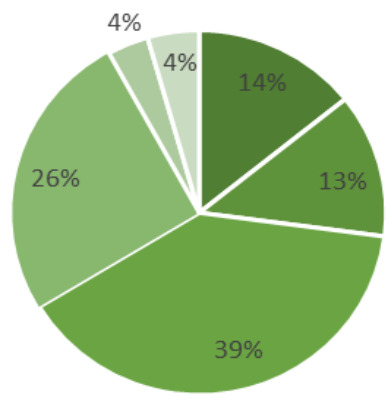

$$
\text { " érettségi } \text { " főiskola }
$$

2. ábra - A minta végzettség szerinti eloszlása

A végzettség szerinti eloszlással kapcsolatos egyik érdekesség, hogy elég magas (29\%) a pedagógusok aránya a mintában.

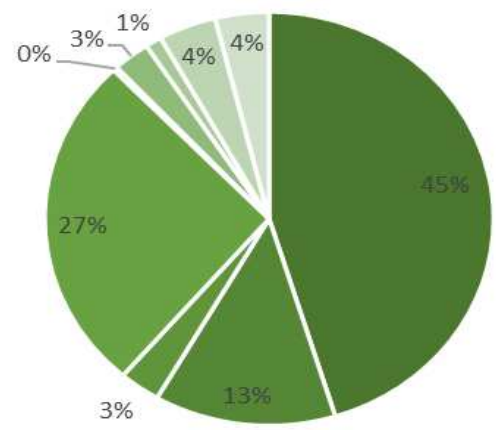

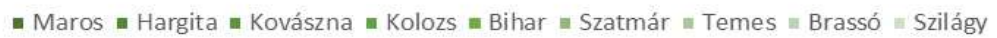

3. ábra - A minta megyék szerinti eloszlása

A kérdőívre Erdély 9 megyéjéböl érkeztek válaszok. A minta megyék szerinti eloszlása a következő (3. ábra): 152-en, azaz a válaszadók 45\%-a Maros megyei, 89-en, azaz 27\% Kolozs, 44-en, azaz 13\% Hargita, 14-en, azaz 4\% Brassó, 13-an, azaz 4\% Szilágy, 10-en, azaz 3\% Kovászna, 9-en, azaz 3\% Szatmár, 4-en, azaz 1\% Temes és 1 Bihar. 
Településtípus szerint (4. ábra) szinte egyenlő arányban vannak képviseltetve a nagyvárosokban (40\%) és a falvakon (42\%) lakó családok, a minta 18\%-a pedig kisvárosban lakik.

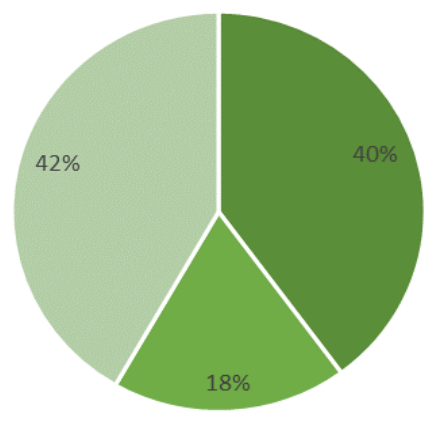

- nagyváros = kisváros = falu, község

4. ábra - A minta településtípus szerinti eloszlása

A kutatásban résztvevő családok túlnyomó többsége a családi állapot szempontjából (5. ábra) házastársi viszonyban él (87\%), 4\%-a elvált, 5\%-a együtt él, de nem házas, 2\%-a gyermekeit egyedül nevelő szülő, 1\%-a mozaikcsaládban él, és 1\%-a özvegy.
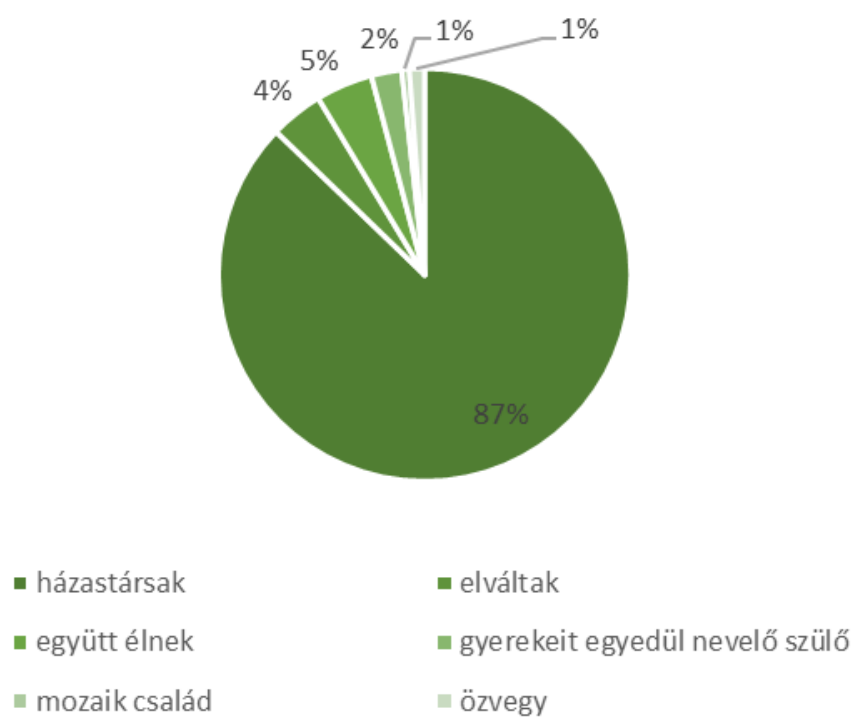

5. ábra - A minta családi állapot szerinti eloszlása 
Vargancsik-Thörik Krisztina Iringó

A családban nevelt gyermekek száma szerint (6. ábra) a minta fele 2 gyermeket nevel, 33\%-a egy gyermeket, 14\%-a 3 gyermeket, 3\%-a 4 gyermeket és egy család 5 gyermeket. A mintát képező 336 család összesen 631 gyermeket nevel, azaz átlagban 1,87 gyermek jut egy családra.

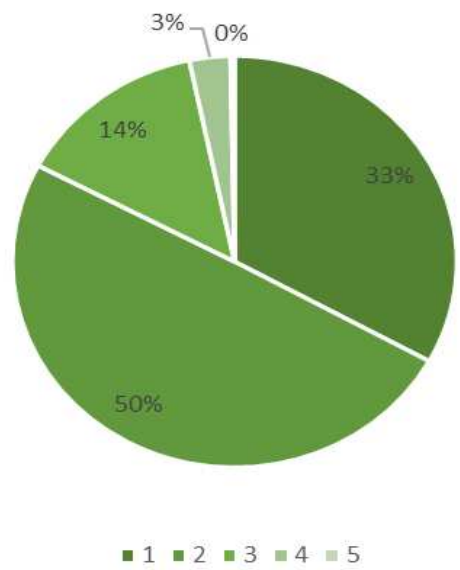

6. ábra - A családban nevelt gyermekek száma szerinti eloszlás

A vizsgált családokban nevelt összesen 631 gyermek életkorát tekintve a következő az eloszlásuk (7. ábra):

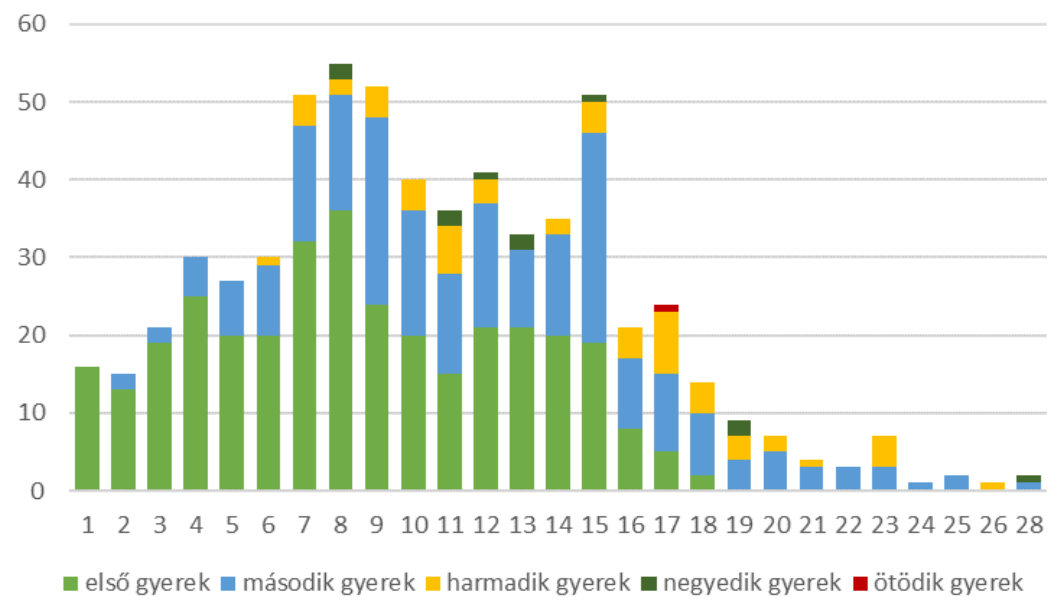

7. ábra - A családokban nevelt gyermekek életkori eloszlása 
A vizsgált családokban a legkisebb gyermek életkora 1 és 18 év közötti, átlagéletkora 8 és fél év, míg a legnagyobb gyermek életkora 3 és 28 év között mozog, átlagéletkora pedig 13 év.

A minta 336 családjában 406 okoseszköz (okostelefon, tablet, laptop) áll a gyermekek rendelkezésére, azaz átlagban 1,2 okoseszköz családonként. 111 családban, azaz a minta 24\%-ában egy gyermek sem rendelkezik okoseszközzel, 128 családban, azaz a minta 38\%-ában egy gyermek rendelkezik saját okoseszközzel, 108 (32\%) családban 2, 18 (5\%) családban 3 és 2 (1\%) családban 4 gyermek (8. ábra).

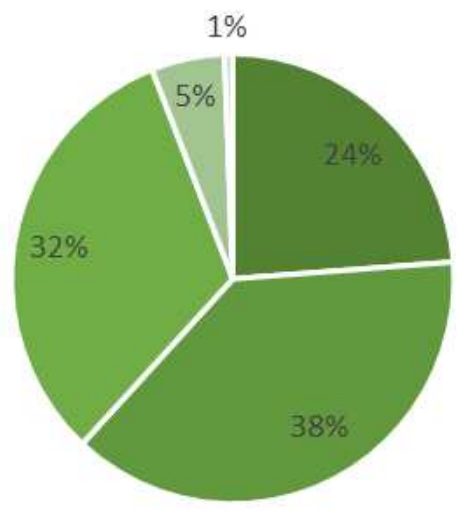

- egyikneksem $=1$ gyereknek $=2$ gyereknek $=3$ gyereknek $=4$ gyereknek

8. ábra - Hány gyermeknek van saját okoseszköze a vizsgált családokban

A gyermekek okoseszközökhöz való napi hozzáférése tekintetében még magasabb az arány (9. ábra), a minta 336 családjában 509 gyermeknek van hozzáférése okoseszközhöz, ami átlagban 1,51 okoseszközt jelent családonként. 38 családban (11\%) egy gyermeknek sincs hozzáférése, 127 családban (38\%) egy gyermeknek, 135 családban (40\%) 2 gyermeknek és 32 családban (10\%) 3 gyermeknek és 4 családban (1\%) 4 gyermeknek van okoseszközhöz való hozzáférése. 
Vargancsik-Thörik Krisztina Iringó

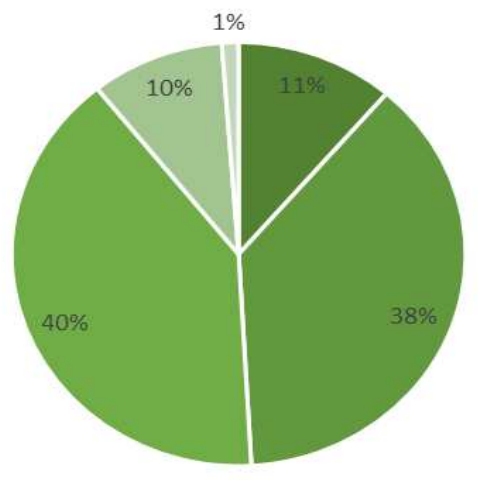

- egyikneksem $=1$ gyereknek $\equiv 2$ gyereknek $=3$ gyereknek $=4$ gyereknek

9. ábra - Hány gyermeknek van napi hozzáférése okoseszközhöz a vizsgált családokban

A mintában vizsgált 336 családból 275 esetében (azaz 81,84\%-ban) rendelkezik valamelyik gyermek okoseszközzel, és átlagosan 8,78 éves korukban kapták az első okoseszközüket, a legtöbben, azaz 62-en (23\%) 10, 35-en (13\%) 7, 31-en (11\%) 8, 30-an (11\%) 11 éves korukban (10. ábra). Megfigyelhető, hogy az átlag az elemi iskola éveire tehető, és a kiemelkedő csúcs az elemi iskolából általános iskolába történő ciklusváltáshoz köthetö.

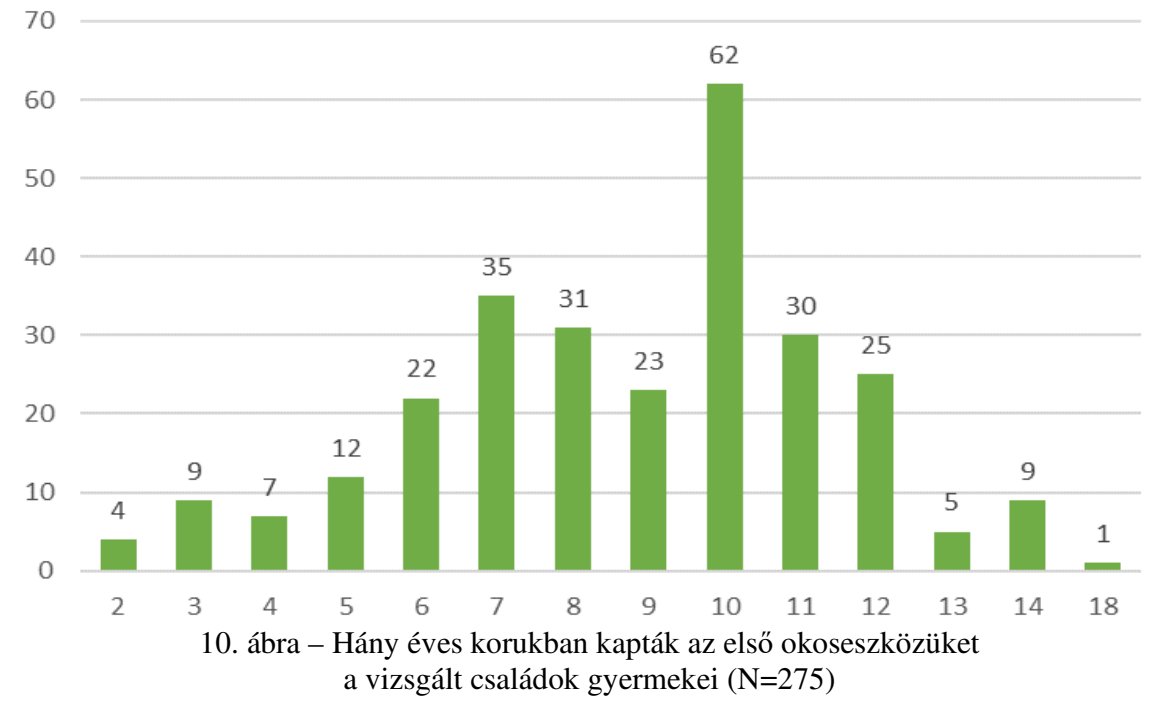


A mintáról tehát elmondható, hogy többségében 40 év körüli, magas fokú végzettséggel rendelkező erdélyi szülőből áll, akik átlagosan 1,87 gyermeket nevelnek (a gyermekek átlagéletkora 13 év). Családonként átlagosan 1,2 okoseszköz áll a gyermekek rendelkezésére, és 1,51 gyermeknek van napi szinten hozzáférése okoseszközökhöz.

\section{A szülők ismeretei a gyerekek online barátkozási szokásairól a közösségi médiában}

A szülők általában érdeklődnek arról, hogy kik a gyermek barátai a közösségi médiában, de mindössze a minta fele állítja azt, hogy mindent tud a gyermek online barátairól, 46\%-ának van némi rálátása, és a minta 4\%-a semmit sem tud erről a témáról, mert ezt a gyermek magánügyének tekinti (11. ábra).

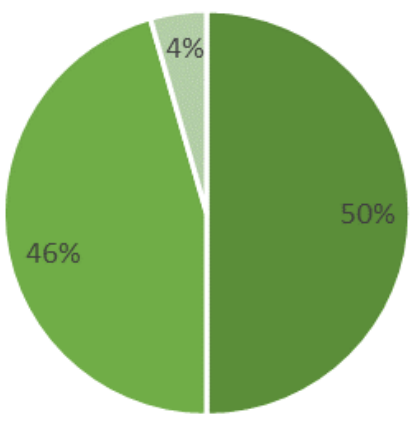

- mindent tudok a gyerek online barátairól

- van némi rálátásom

" semmit sem tudok a gyerek online barátairól, ez az ő magánügye

11. ábra - Ön érdeklődik-e arról, hogy kik a gyermeke barátai a közösségi médiában?

Jelentős eltérés tapasztalható a szülőknek ehhez a kérdéshez való hozzáállásában a gyermekek számának függvényében (Pearson Chi-Square $\mathrm{T}=20.611$, df=8, $\mathrm{p}=0.008$ ). A 12. ábrán látható, hogy a mindent tudok aránya folyamatosan csökken a gyermekek számának növekedésével, míg az egy gyermeket nevelö családok esetében eléri az 55,45\%-ot, két gyermek esetében 43,11\%-ra, három gyermek esetében 23,4\%-ra, négy gyermek esetében pedig 20\%-ra csökken. Ugyanakkor a semmit sem tudok, ez a gyermek magánügye válasz aránya a legalacsonyabb az egy gyermeket nevelő családokban (2,7\%), a kétgyermekes családok esetében 4,79\%, a háromgyermekes családok esetében pedig 12,76\%. 
Vargancsik-Thörik Krisztina Iringó

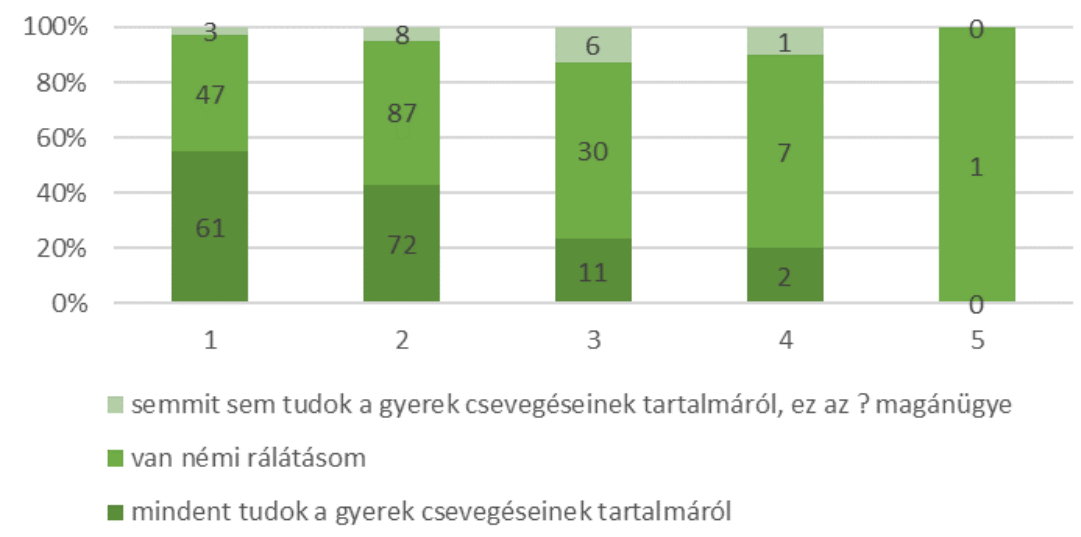

12. ábra - Az Ön érdeklődik-e arról, hogy kik a gyermeke barátai a közösségi médiában kérdésre adott válaszok a gyermekek számának függvényében

Jelentős eltérés tapasztalható a szülőknek ehhez a kérdéshez való hozzáállásában a szülők életkora függvényében (Pearson Chi-Square $\mathrm{T}=59.814, \mathrm{df}=12, \mathrm{p}=0.000$ ). A 13. ábrán látható, hogy a mindent tudok válaszok aránya folyamatosan csökken a szülök életkorának előrehaladtával, és a van némi rálátásom aránya folyamatosan nő.

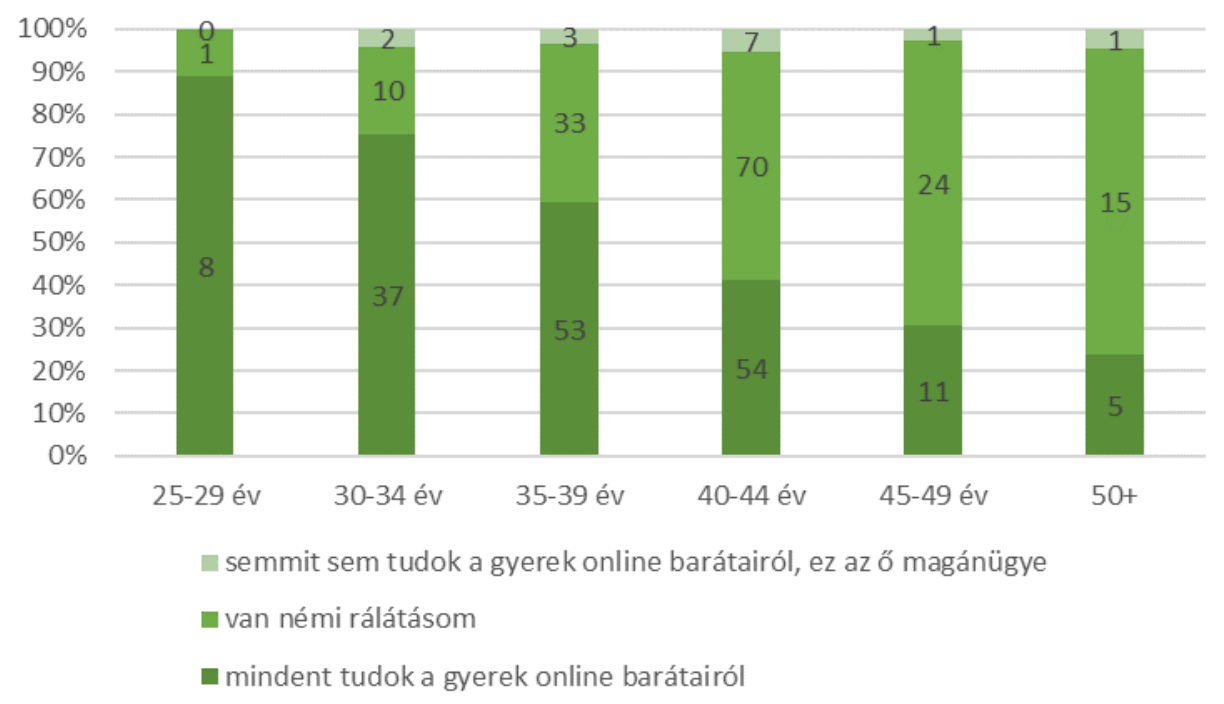

13. ábra - Az Ön érdeklődik-e arról, hogy kik a gyermeke barátai a közösségi médiában kérdésre adott válaszok a szülők életkorának függvényében 
Jelentős eltérés tapasztalható a szülőknek ehhez a kérdéshez való hozzáállásában a szülők végzettsége függvényében (Pearson Chi-Square $\mathrm{T}=19.566, \mathrm{df}=10, \mathrm{p}=0.034$ ) is. A 14. ábrán látható, hogy a mindent tudok aránya a legmagasabb az érettségivel vagy az ennél alacsonyabb végzettséggel rendelkezők esetében (60\%), míg az magasabb szintü végzettséggel rendelkező szülők több mint fele csak rálátással rendelkezik, vagy semmit sem tud a gyermekei online barátairól (ez az arány az egyetemi alapképzéssel rendelkezők esetében 50,75\%, az egyetemi mesterképzés esetében 47,67\%, a doktori képzés esetében $41,66 \%$, míg a föiskolával rendelkezők esetében 39,53\%). Ugyanakkor a semmit sem tudok aránya a legmagasabb az érettségivel sem rendelkezők körében (20\%).

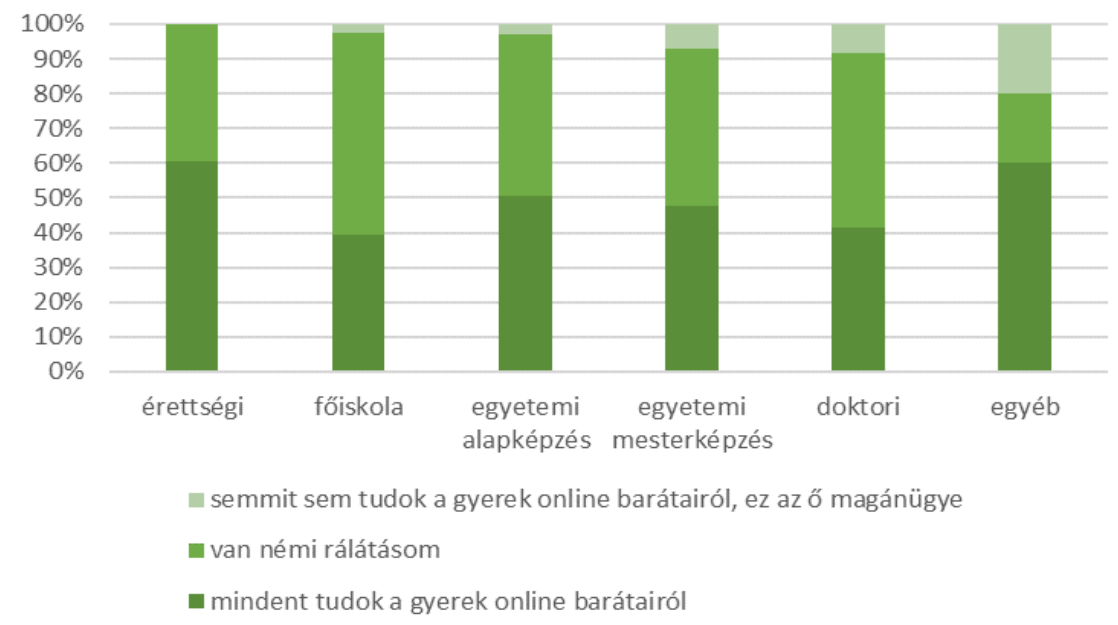

14. ábra - Az Ön érdeklödik-e arról, hogy kik a gyermeke barátai a közösségi médiában kérdésre adott válaszok a szülők végzettségének függvényében

Arról is érdeklődtünk, hogy ismerik-e a szülők a gyermekek közösségi médiában való csevegéseinek tartalmát. A szülők 44\%-a azt állítja, hogy mindent tud a gyermeke(i) csevegéseinek tartalmáról, 51\%-ának van némi rálátása, és 5\%-ának fogalma sincs, hiszen úgy gondolja, hogy ez a gyermek magánügye (15. ábra).

Jelentős az eltérés a gyermek csevegéseinek tartalmával kapcsolatos ismeretek tekintetében a különböző korosztályú szülők között (Pearson Chi-Square T=61.987, $\mathrm{df}=12, \mathrm{p}=0.000$ ). Azon szülők aránya, akik mindent tudnak gyermekeik csevegésének tartalmáról, folyamatosan csökken a szülők korának elörehaladtával, azon szülők aránya pedig, akik semmit sem tudnak erről a témáról, ingadozó: legmagasabb az 50 év feletti szülők esetében $(19,04 \%)$, de 5\% körüli a 30-34 éves $(6,12 \%)$, a $45-49$ éves $(5,55 \%)$, illetve a 35-39 éves (4,49\%) szülők körében is (16. ábra). 


\section{Vargancsik-Thörik Krisztina Iringó}

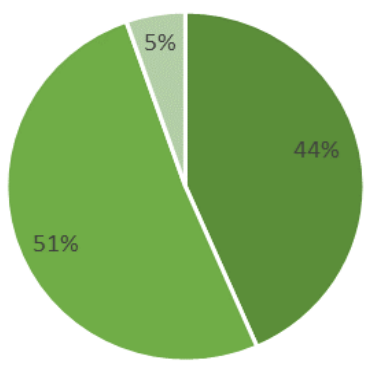

- mindent tudok a gyerek csevegéseinek tartalmáról

- van némi rálátásom

" semmit sem tudok a gyerek csevegéseinek tartalmáról, ez az ő magánügye

15. ábra - Az Ön érdeklődik-e arról, hogy miről cseveg a gyermeke a közösségi médiában? kérdésre adott válaszok

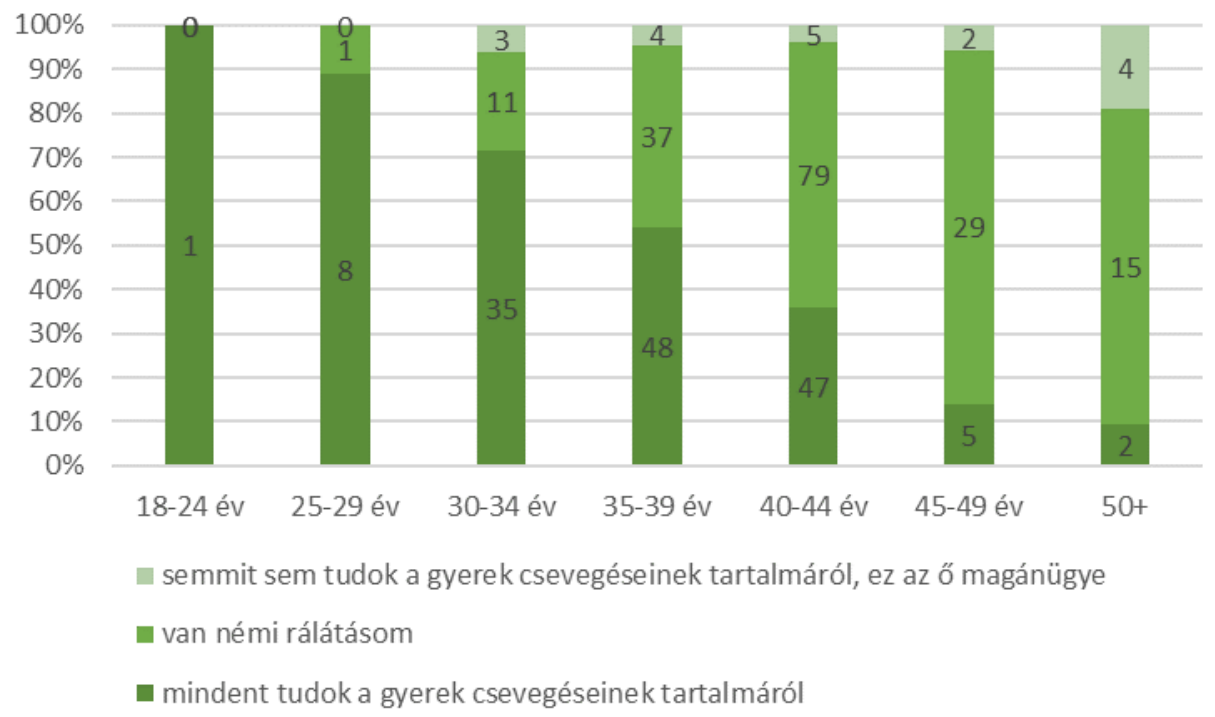

16. ábra - Ön érdeklödik-e arról, hogy miről cseveg a gyermeke a közösségi médiában? kérdésre adott válaszok a szülök életkorának függvényében 
Jelentős az eltérés a gyermek csevegéseinek tartalmával kapcsolatos ismeretek tekintetében a pedagógus és egyéb végzettségü szülők között (Pearson Chi-Square $\mathrm{T}=9.845, \mathrm{df}=2, \mathrm{p}=0.007$ ). A pedagógus szülők esetében alacsonyabb azok aránya, akik mindent tudnak a gyermek csevegéseinek tartalmáról $(34,34 \%)$ és azok aránya is nagyon alacsony, akik semmit sem tudnak róla $(2,02 \%)$, tehát a pedagógusok gyakrabban választják az arany középutat, azaz van rálátásuk a gyermek csevegéseire, de nem tartják folyamatos ellenőrzés alatt. A nem pedagógus szülök esetében sokkal magasabb a mindent tudok a gyermek csevegéseinek tartalmáról válaszok aránya (47,25\%), és a semmit sem tudok válaszok aránya is magasabb $(6,75 \%)$ (17. ábra).

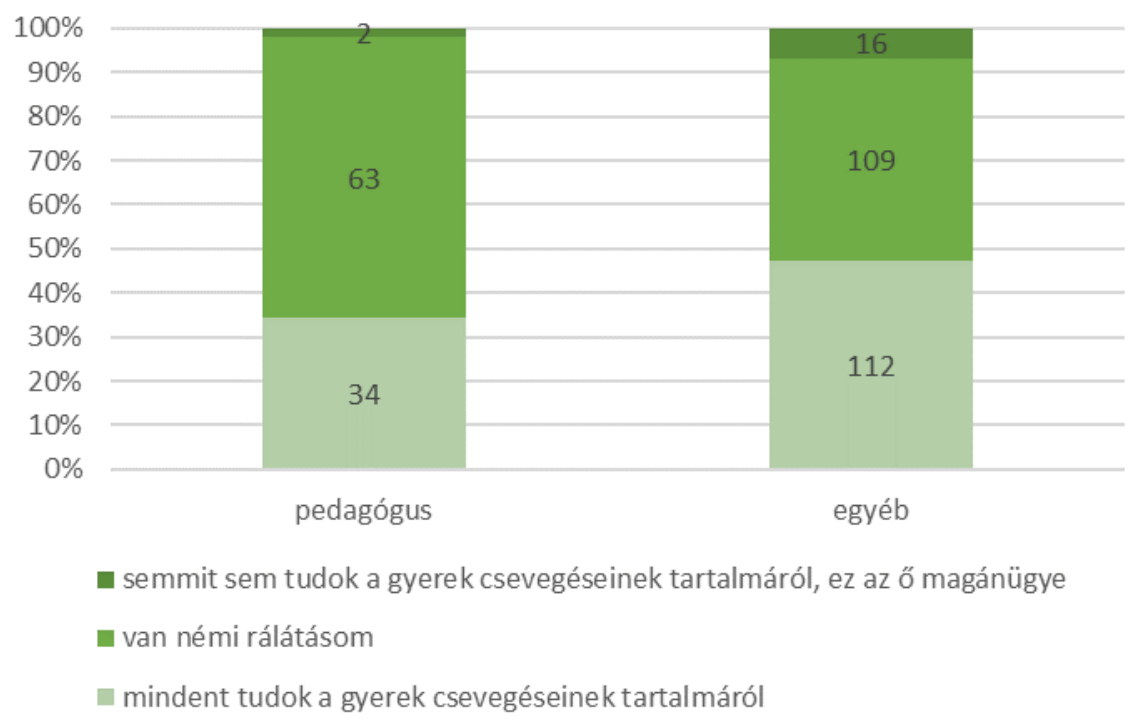

ábra - Az Ön érdeklödik-e arról, hogy miről cseveg a gyermeke a közösségi médiában? kérdésre adott válaszok a szülők foglalkozásának függvényében

Összefoglalásként a gyermekek közösségi médián keresztüli kapcsolatai tekintetében kockázati tényezőt jelent a családban nevelt gyerekek száma (a több gyerekkel rendelkező családokban csökken a szülők rálátása arra, hogy kivel barátkoznak a gyermekek az online térben) és a szülők életkora (a szülök életkorának növekedésével csökken a gyerek szociális médián keresztül ápolt kapcsolatai iránti érdeklődés).

A gyermekek közösségi médián keresztüli kommunikációjának tartalma tekintetében is van a szülők jelentős részének rálátása, ugyanakkor a szülő életkorának előrehaladtával nő a „semmit sem tudok” válaszok aránya. A pedagógusszülők körében elterjedtebb, hogy nem akarnak mindent tudni a gyermekek online kommunikációjának tartalmáról, ami azt 
Vargancsik-Thörik Krisztina Iringó

feltételezi, hogy az aktív mediációt részesítik előnyben a folyamatos ellenőrzéssel szemben.

\section{A közösségi média hatása a gyerekekre}

A megkérdezett szülők 34\%-a figyelt meg változást a gyermeke fejlődésében a közösségi média hatására. Ezek a hatások nagyon vegyesek, pozitívak vagy negatívak, így a könnyebb követhetőség kedvéért táblázatos formában mutatjuk be a beérkezett válaszokat:

1. táblázat - A közösségi média hatásai a gyermekekre a szülök megfigyelései alapján

\begin{tabular}{|c|c|}
\hline Pozitív hatás & Negatív hatás \\
\hline $\begin{array}{l}\text { - nyitottabb } \\
\text { - szélesebb a látóköre } \\
\text { - figyelmesebb } \\
\text { - óvatosabb } \\
\text { - könnyebben barátkozik } \\
\text { - hasznos információkat gyüjt } \\
\text { - tájékozottabb } \\
\text { - új szavakat tanul (angol, } \\
\text { - kíváncsibb } \\
\text { - tapasztaltabb } \\
\text { - többet, jobban kommunikál }\end{array}$ & $\begin{array}{l}\text { - } \text { elszigetelődik a családtól } \\
\text { - felpörög } \\
\text { - bizalmatlanabb az online } \\
\text { kapcsolatokban } \\
\text { - romlik a tanulási eredménye } \\
\text { - figyelmetlenebb } \\
\text { - agresszívabb } \\
\text { - szorong } \\
\text { - ingerült, indulatos } \\
\text { - beszükült } \\
\text { - kevesebbet olvas }\end{array}$ \\
\hline
\end{tabular}

A válaszok kapcsán megfigyelhető, hogy a szülők legnagyobb része vagy csak negatív, vagy csak pozitív hatásra ad példát, és alig akad egy-két olyan szülő, aki pozitív és negatív hatásokról egyaránt beszámol. Ugyanakkor egyesek a gyermek általános fejlődésével, életkori sajátosságaival is párhuzamba hozzák a hatásokat, ami fokozottabb szülői tudatosságra utal.

„Többet mesél például az osztálytársairól, többször alkot véleményt közösségi problémákat érintő dolgokban, szívesebben olvas és mesél is. Az osztálytársakkal való csevegést illetően korából fakadóan eléggé diszkrét, nem tereget ki mindent, de kihámozható. A 7 éves gyermekem viszont a nyári vakációban 1 órás tablethasználat után egy fél óráig nagyon felpörög. Neki csengő jelzi, hogy lejárt az eszközhasználat órája. Ö nehezebben hagyja abba a játékot, de a szabály, az szabály" - számol be egy édesanya.

A szülők legnagyobb része látja az okoseszközök használatában rejlő lehetőségeket, és amint az a 18. ábrán is látszik, a nyitott kérdésre adott válaszaikból az információ és a tanulás emelkedik ki. 


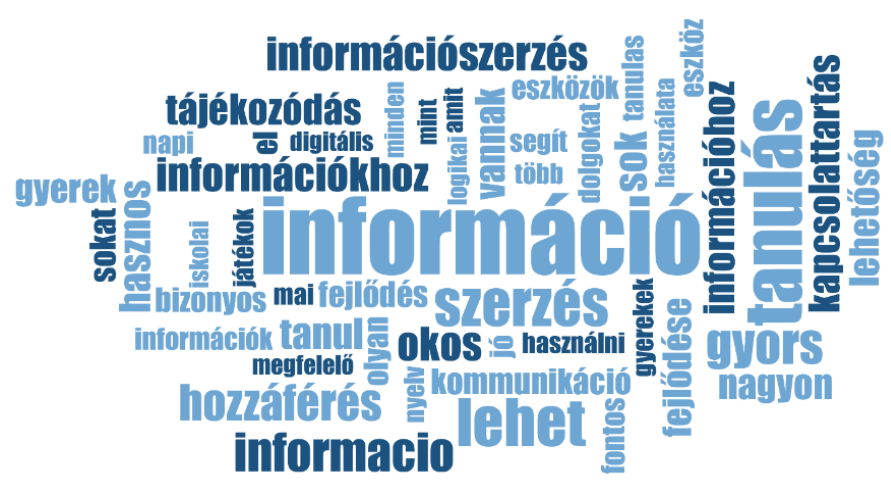

18. ábra - Az okoseszközök használatában rejlő lehetőségek szófelhője

Az okoseszközök használatában rejlö lehetöségek tekintetében a beérkezett válaszokat 8 kód mentén csoportosítottuk a MAXQDA segítségével (gyors információszerzés és tájékozódás, tanulás-fejlődés, kapcsolattartás, semmilyen lehetőség nincs benne, kikapcsolódás, munkavégzés-ügyintézés, önállóság, ismeretközlés), és ezek megjelenésének mértéke a 19. ábrán látható.

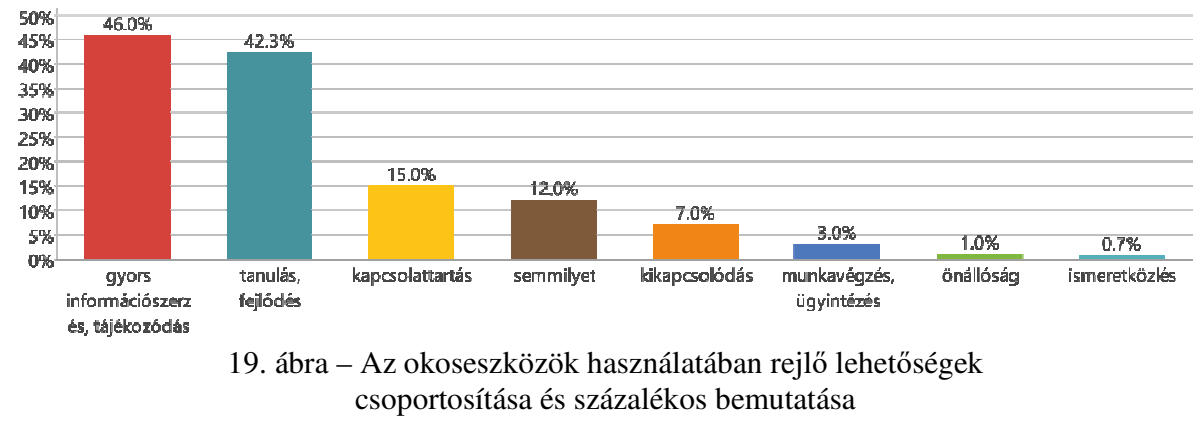

Látható, hogy a két kiemelkedően magas számban megjelent válasz a gyors információszerzéssel és tájékozódással (46\%), valamint a tanulással és fejlődéssel (42,3\%) kapcsolatos.

Természetesen nem csak lehetőségeket, hanem kockázatokat is látnak a szülők az okoseszközök használatában (20. ábra). Ezekből a függőség kialakulása emelkedik ki jelentősen. 


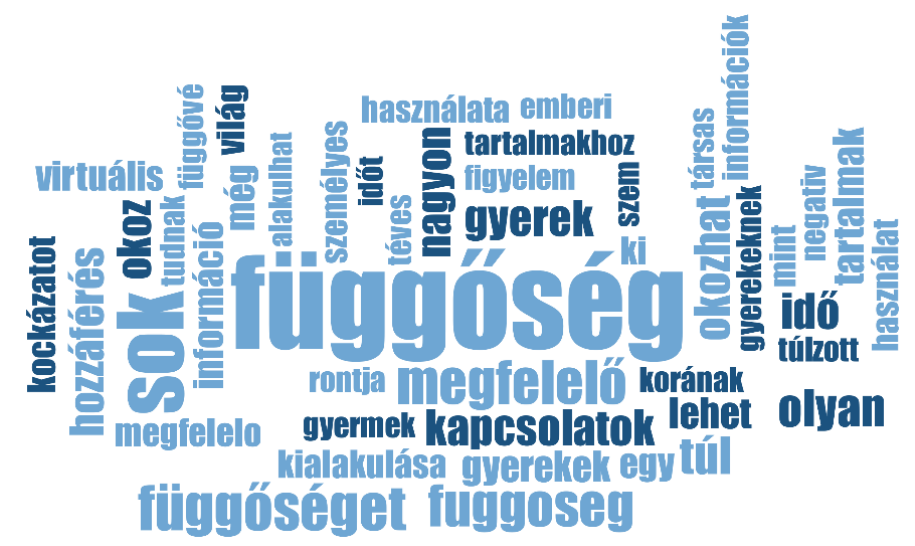

20. ábra - Az okoseszközök használatában rejlő kockázatok szófelhője

A szülőknek az okoseszközök használatában rejlő kockázatokra vonatkozó válaszait 8 kód mentén csoportosítottuk a MAXQDA segítségével, és ezek megjelenésének mértéke a 21. ábrán látható. Legmagasabb arányban a függőség kialakulásának kockázata jelenik meg (40,6\%), ezt követi a nem megfelelő tartalmakhoz való hozzáférés, egészségügyi problémák (látás romlása, sugárzás hatása, helytelen testtartás stb.), beszűkülő társas kapcsolatok, adatvédelmi és biztonsági problémák, fölösleges időtöltés, a valóságtól való eltávolodás és a beszükülö tevékenységek köre.

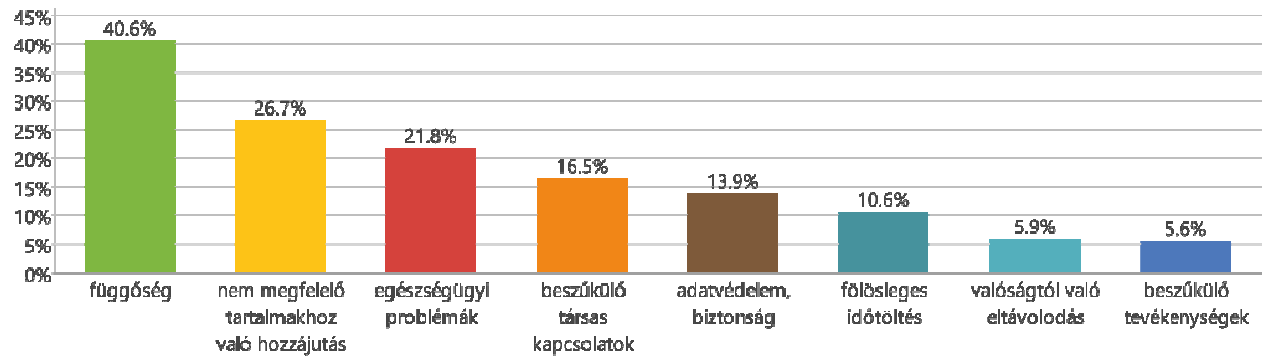

21. ábra - Az okoseszközök használatában rejlő kockázatok csoportosítása és százalékos bemutatása

A szülők véleménye a közösségi médiának a gyermekeikre gyakorolt hatásának tekintetében sarkított, hiszen vagy csak a jó, vagy csak a rossz hatásokat említik. A pozitív hatások köréből kiemelkedik a gyors információszerzés és tájékozódás, valamint a tanulás és fejlődés. Negatív hatásként a legtöbb szülő a függőség kialakulását és a nem megfelelő tartalmakhoz való hozzáférést emelte ki. 


\section{Szülői beavatkozás a gyerekek médiahasználatába}

A szülök 93\%-a szerint kell tenni valamit annak érdekében, hogy a gyermekek kevesebb időt töltsenek online, és $91 \%$-uk tesz is ennek érdekében, de sikerességüket tekintve 1-től 5-ig terjedő Linkert-skálán az átlag 3,48, és mindössze 23,51\%-uk vallja nagyon sikeresnek magát.

A szülők 70,53\%-a nagyon fontosnak tartja a szülöi szürést, és több mint fele (52\%) alkalmaz is valamilyen szürési lehetőséget.

Jelentős az eltérés a szülői szürés fontosságának tekintetében a korosztályok között: a szülők életkorának növekedésével már nem ítélik annyira fontosnak a szürést (Pearson Chi-Square $\mathrm{T}=78.877, \mathrm{df}=24, \mathrm{p}=0.000$ ). Míg a 25-29 éves szülök 90\%-a tartja nagyon fontosnak a szürést, ez 30-34 éves korra 87,5\%-ra, 35-39 éves korra 78,16\%-ra, 40-44 éves korra 69,53\%-ra, 45-49 éves korra 63,88\%-ra és 50 év felett $35 \%$-ra csökken (22. ábra).

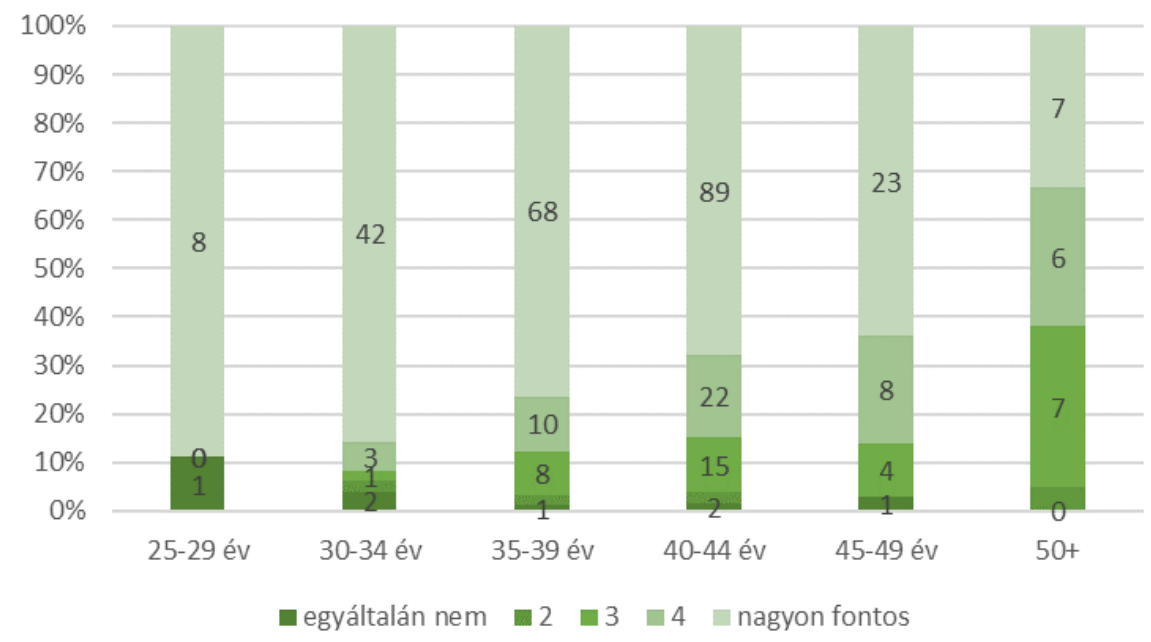

22. ábra - A szülői szürés fontosságának megítélése a szülők életkorának függvényében

A kutatás mintájában szereplő 336 család 80,08\%-ában vannak az okoseszközök használatára vonatkozó szabályok. Ezek leggyakrabban időkorlátozásban merülnek ki (66,5\%), de vannak a tanuláshoz/tanulási eredményekhez között szabályok (28,6\%), a nézhető tartlamakra vonatkozó szabályok (16,7\%), van olyan család, ahol a felnőtt felügyelete alatt lehet használni az okoseszközt, illetve vannak eszközhöz kötött korlátozások is (7,8\%) (23. ábra). 
Vargancsik-Thörik Krisztina Iringó

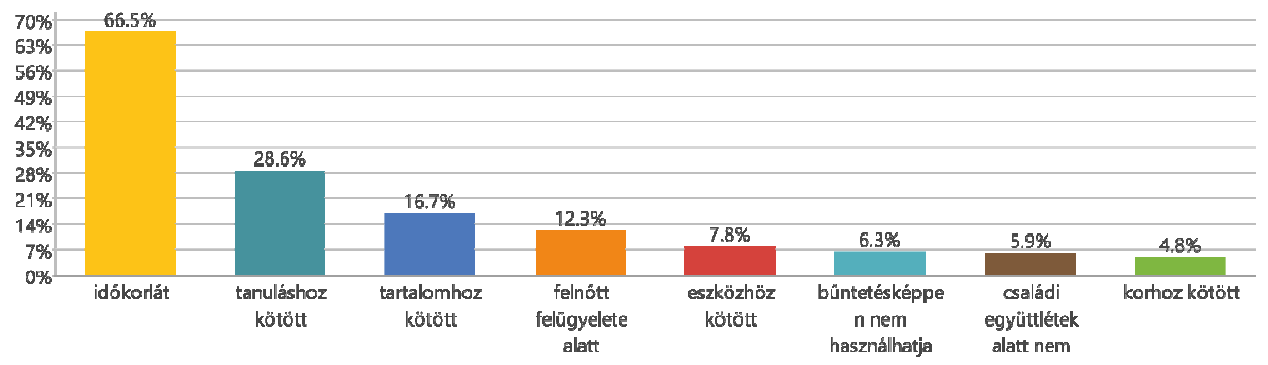

23. ábra - Az okoseszközök használatára vonatkozó szabályok

Érdekes megfigyelni, hogy a szülők által felsorolt okoseszköz-használatra vonatkozó szabályok között szinte mindegyik korlátozó és a válaszok megfogalmazásából ítélve szinte egyáltalán nem jellemző az aktív mediáció az erdélyi családokban, azaz nem magyaráznak, beszélgetnek a médiatartalmakról, hanem inkább megtiltják, vagy szigorú korlátok közé szorítják a hozzáférést. Ez a szülői viselkedésforma nem segíti a gyermekek médiatudatosságának fejlődését, így nem tudnak olyan kritikus készségekre szert tenni, amelyek megtanítják őket a médiaüzenetek hatékony kezelésére és ezáltal a médián keresztüli manipuláció elkerülésére.

\section{Következtetések}

A kutatás során feltételezéseink jelentős része beigazolódott. Az erdélyi családokban erőteljesen jelen vannak az okoseszközök, hiszen az átlagosan 1,87 gyermeket nevelö családokban 1,2 okoseszköz áll a gyermekek rendelkezésére, és 1,51 gyermeknek van napi szinten hozzáférése okoseszközökhöz.

A szülők felének csak némi rálátása van, vagy semmit sem tud gyerekei online barátairól, és ebben a tekintetben kockázati tényezőt jelent a családban nevelt gyerekek száma (a több gyerekkel rendelkezö családokban csökken a szülök rálátása arra, hogy kivel barátkoznak a gyermekek az online térben) és a szülök életkora (a szülők életkorának növekedésével csökken a gyerek szociális médián keresztül ápolt kapcsolatai iránti érdeklödés).

Hasonlóképpen, a gyermekek közösségi médián keresztüli kommunikációjának tartalma tekintetében a szülők 56\%-ának csak némi rálátása van, vagy semmit sem tud erről, és a szülő életkorának előrehaladtával nő a „semmit sem tudok” válaszok aránya. A pedagógusszülök körében az átlagosnál magasabb, hogy nem tudnak mindent a gyermekek online kommunikációjának tartalmáról, ami arra enged következtetni, hogy ők az aktív mediációt részesítik előnyben a folyamatos ellenőrzéssel szemben.

A közösségi média gyermekeikre gyakorolt hatásának tekintetében a szülök véleménye sarkított, hiszen vagy csak a jó, vagy csak a rossz hatásokat említik. A pozitív 
hatások köréből kiemelkedik a gyors információszerzés és tájékozódás, valamint a tanulás és fejlődés. Negatív hatásként a legtöbb szülő a függőség kialakulását és a nem megfelelö tartalmakhoz való hozzáférést emelte ki.

A szülök által felsorolt, okoseszköz-használatra vonatkozó szabályok közül szinte mindegyik korlátozó, és a válaszok megfogalmazásából ítélve szinte egyáltalán nem jellemző az aktív mediáció az erdélyi családokban, azaz nem magyaráznak, beszélgetnek a médiatartalmakról, hanem inkább megtiltják vagy szigorú korlátok közé szorítják a hozzáférést. Ez a szülői viselkedésforma nem segíti a gyermekek médiatudatosságának fejlődését, így nem tudnak olyan kritikus készségekre szert tenni, amelyek megtanítják őket a médiaüzenetek hatékony kezelésére és ezáltal a médián keresztüli manipuláció elkerülésére.

\section{KÖNYVÉSZET}

EUROSTAT, 2020. Digital economy and society statistics - households and individuals - statistics explained [online]. [Letöltés időpontja: 2021.03.20.] Elérhető: https://ec.europa.eu/eurostat/statisticsexplained/index.php?title=Digital_economy_and_digital_society_statistics_at_re gional level

FUJIOKA, Y. és AUSTIN, E. W., 2002. The relationship of family communication patterns to parental mediation styles. Communication Research, Vol. 29 (6), 642-665.

LIVINGSTONE, S., HADDON, L., GÖRZIG, A. és ÓLAFSSON, K., 2011. Risks and safety on the internet: The perspective of European children. Full Findings. LSE, London: EU Kids Online.

LIVINGSTONE, S. és HELSPER, E., 2008. Parental mediation and children's Internet use [online]. Journal of broadcasting \& electronic media, Vol. 52 (4), 581-599. [Letöltés időpontja: 2021.03.20.] Elérhetö: http://eprints.lse.ac.uk/25723/

VALKENBURG, P.M., KRCMAR, M., PEETERS, A.L. és MARSEILLE, N.M., 1999. Developing a scale to assess three styles of television mediation: "instructive mediation," "restrictive mediation," and "social coviewing". Journal of Broadcasting \& Electronic Media, Vol. 43., 1999; 52-66.

144/2020.08.24-es Sürgősségi Kormányrendelet - OUG nr. 144 din 24 august 2020 privind unele măsuri pentru alocarea de fonduri externe nerambursabile necesare desfășurării în condițiile de prevenție a activităților didactice aferente anului școlar/universitar 2020/2021 în contextul riscului de infecție cu coronavirus SARS-CoV-2 [online]. [Letöltés időpontja: 2021.03.20.] Elérhető: http://legislatie.just.ro/Public/DetaliiDocument/229542. 